\title{
A grand challenge for environmental toxicity: what are the permissive limits of toxic pollutants in the environment?
}

\section{Donat-P. Häder*}

Emeritus from the Department of Biology, Friedrich-Alexander Universität, Erlangen-Nürnberg, Germany

*Correspondence: donat@dphaeder.de

Edited by:

Aziz Ullah, Kohat University of Science and Technology, Pakistan

Reviewed by:

Rajeshwar P. Sinha, Banaras Hindu University, India

Keywords: toxicity, pollutants, environmental monitoring, inorganic toxins, organic toxins

Environmental pollution is one of the major threats to the biota and public health. The growing world population produces increasing amounts of toxins which accumulate in water, air, and soil. Especially in developing countries indiscriminate disposal of industrial and municipal wastes, vehicle emissions and improper application of pesticides and fertilizers in agriculture are main factors for increasing pollution (Lone et al., 2008). Persistent organic pollutants (POP) arise from accidental spillage or untreated emissions (Gao et al., 2008; Harrad, 2010; Zhou et al., 2013). In order to protect the environment and the public, permissive limits have been defined for many organic and inorganic toxins by national and international agencies (WHO, 2008). Limits for various pollutants can vary between countries and are sometimes adapted, e.g., when new research results indicate a health hazard at lower concentrations than previously assumed. The recommendation of the Federal Health Office in Germany for the concentration of nitrate in drinking water from 1986 was replaced by the recommendation of the Drinking Water Commission in 2003, which defines the permissive limit at $50 \mathrm{mg} \mathrm{L}^{-1}$ (Grummt, 2007). The bigger problem is that defined limits are not always observed, especially in developing countries. e.g., the WHO standard for arsenic in ground water is $10 \mu \mathrm{g} \mathrm{L}^{-1}$; this value is exceeded manifold in East Punjab, Pakistan, where concentrations of 32-1900 $\mu \mathrm{g} \mathrm{L}^{-1}$ have been found (Farooqi et al., 2007).

For some health hazards no firm limits can be defined. The doses for exposure of humans to radioactivity have been devised with respect to the natural exposure to radiation from the Earth (such as from radon and uranium) and ionizing radiation from outer space. The average exposure on Earth is $\approx 0.01 \mathrm{mSv} /$ day, but in some areas it may be 5-fold higher. Astronauts in the International Space Station are exposed to $\approx 1 \mathrm{mSv} /$ day. High-dose radiation of $>150 \mathrm{mSv}$ causes often serious immediate effects on humans (Bonner, 2003). At low doses the effects of radiation result from the interaction of the radiation with the cellular DNA. The higher the radiation, the higher is the chance for DNA defects and mutations which may eventually lead to cancer (Tubiana et al., 2009). Consequently, decreasing the exposure reduces the health risk, but there is no firm lower limit; even a single hit can modify the DNA. As an example, lung cancer mortality was studied in 1415 Swedish iron miners who were exposed to short-lived derivatives of radon close to the currently accepted occupational limit. 50 deaths from lung cancer were observed between 1951 and 1976, in contrast to 12.8 expected (Radford and St. Clair Renard, 1984).

When defining standards for pollutants, other environmental factors need to be considered. Especially organic substances can change under the influence of $\mathrm{pH}$ in water or when exposed to intense solar radiation. These products may or may not have a different toxicity. Things are even more complicated with mixtures of different pollutants. When doing a chemical analysis of ground, drinking or waste water, the laboratory work soon exceeds the economical limits, since it is not possible to test for the thousands of potentially damaging chemicals. e.g., 2, 3, 7, 8-tetrachlorodibenzo-p-dioxin
(2,3,7,8-TCDD), also known as dioxin had not been synthesized for commercial purposes except as a test chemical for research. Therefore, there was no routine testing until it caused the Seveso poisoning in Italy (Geyer et al., 1986).

So, how can we judge whether or not a given toxin-or even worse-a mixture of pollutants exceeds the safe threshold. Since it is unethical to test this on humans, plants and animals such as fish are being used to determine safe thresholds (Klauck, 2013). In order to avoid animal tests and to automate, facilitate and standardize environmental monitoring we have developed a biotest based on on-line computerized image analysis of the movement parameters in swimming microorganisms (Tahedl and Häder, 2000). A number of end points, such as the cell morphology, motility, swimming velocity and orientation of the flagellates with respect to the gravity vector of the Earth are being determined in thousands of cells providing sensitive, fast, inexpensive and reliable tests of the biological safety for the biota in aquatic habitats (Ahmed and Häder, 2010). This Ecotox test system has been used to monitor water treatment plants in Germany (Streb et al., 2006), detect toxins in industrial and municipal effluents in Pakistan (Azizullah et al., 2011) or the pollution level in lakes and rivers in Argentina and Egypt (Ahmed, 2010) as well as the effects of gamma-ray radiation in Japan (Sakashita et al., 2002).

Frontiers in Environmental Toxicity is envisioned as a platform to present novel approaches for monitoring environmental safety, detecting and mitigating potential pollution, preventing accidental or intentional release of toxic substances into 
the environment which, alone or in conjunction with other pollutants and the prevailing environmental factors, threaten the biota in water, soil, and air. These immense tasks will be important for a future world with growing populations, changing environmental conditions and technological as well as demographic developments.

\section{REFERENCES}

Ahmed, H. (2010). Biomonitoring of Aquatic Ecosystems, Dept. Biology. Ph.D. thesis, Friedrich-Alexander-Universität, ErlangenNürnberg.

Ahmed, H., and Häder, D.-P. (2010). Rapid ecotoxicological bioassay of nickel and cadmium using motility and photosynthetic parameters of Euglena gracilis. Env. Exp. Bot. 69, 68-75. doi: 10.1016/j.envexpbot.2010.02.009

Azizullah, A., Richter, P., and Häder, D.-P. (2011). Ecotoxicological evaluation of wastewater samples from Gadoon Amazai Industrial Estate (GAIE), Swabi, Pakistan. Int. J. Environ. Sci. 1, 959-976.

Bonner, W. M. (2003). Low-dose radiation: thresholds, bystander effects, and adaptive responses. Proc. Natl. Acad. Sci. U.S.A. 100, 4973-4975. doi: 10.1073/pnas.1031538100

Farooqi, A., Masuda, H., and Firdous, N. (2007). Toxic fluoride and arsenic contaminated groundwater in the Lahore and Kasur districts, Punjab, Pakistan and possible contaminant sources. Environ. Pollut. 145, 839-849. doi: 10.1016/j.envpol.2006.05.007

Gao, J., Liu, L., Liu, X., Zhou, H., Huang, S., and Wang, Z. (2008). Levels and spatial distribution of chlorophenols-2, 4.Dichlorophenol 2, 4, 6trichlorophenol, and pentachlorophenol in surface water of China. Chemosphere 71, 1181-1187. doi: 10.1016/j.chemosphere.2007.10.018
Geyer, H. J., Scheunert, I., Filser, J. G., and Korte, F. (1986). Bioconcentration potential (BCP) of 2, $3,7,8$-Tetrachlorodibenzop-dioxin $(2,3,7,8$ TCDD) in terrestrial organisms including humans. Chemosphere 15, 1495-1502. doi: 10.1016/00456535(86) $90430-3$

Grummt, H.-J. (2007). Die Trinkwasserbeschaffenheit in Deutschland. Bundesgesundheitsblatt Gesundheitsforschung - Gesundheitsschutz 50, 276-283.

Harrad, S., (ed.). (2010). Persistent Organic Pollutants, Chichester: John Wiley \& Sons, Ltd. doi: 10.1002/9780470684122

Klauck, C. R., Rodrigues, M. A. S., and da Silva, L. B. (2013). Toxicological evaluation of landfill leachate using plant (Allium cepa) and fish (Leporinus obtusidens) bioassays. Waste Managem. Res. 31, 1148-1153. doi: 10.1177/0734242X13502388

Lone, M., He, Z., Stoffella, P. J., and Yang, X. (2008). Phytoremediation of heavy metal polluted soils and water: progresses and perspectives. J. Zhejiang Univ. Sci. B 9, 210-220. doi: 10.1631/jzus.B0710633

Radford, E. P. and St. Clair Renard, K. G. (1984). Lung cancer in Swedish iron miners exposed to low doses of radon daughters. $N$. Engl. J. Med. 310, 1485-1491. doi: 10.1056/ NEJM198406073102302

Sakashita, T., Doi, M., Yasuda, H., Fuma, S. and Häder, D.-P. (2002). Protection of negative gravitaxis in Euglena gracilis $\mathrm{Z}$ against gamma-ray irradiation by Trolox, C. J. Radiat. Res. 43(Suppl.), S257-S259. doi: 10.1269/ jrr.43.S257

Streb, C., Richter, P., and Häder, D.-P. (2006) "ECOTOX—a biomonitoring system for UVeffects and toxic substances," in Environmental UV Radiation: Impact on Ecosystems and Human Health and Predictive Models, NATO Science Series, IV Earth and Environmental Sciences, Vol. 57, eds F. Ghetti, G. Checcucci, and J. F. Bornman (Heidelberg: Springer), 288.

Tahedl, H., and Häder, D.-P. (2000). "Use of image analysis in ecotoxicology," in Image Analysis: Methods and Applications, ed D. P. Häder (Boca Raton, FL: CRC Press), 447-458.

Tubiana, M., Feinendegen, L. E., Yang, C. and Kaminski, J. M. (2009). The linear nothreshold relationship is inconsistent with radiation biologic and experimental data. Radiology, 251, 13-22. doi: 10.1148/radiol. 2511080671

WHO. (eds.). (2008). Guidelines for Drinking-Water Quality. Geneva: WHO.

Zhou, Z., Liang, Y., Shi, Y., Xu, L., and Cai, Y. (2013). Occurrence and transport of perfluoroalkyl acids (PFAAs), including short-chain PFAAs in tangxun lake, China. Environ. Sci. Technol. 47, 9249-9257. doi: 10.1021/es40 $2120 \mathrm{y}$

Received: 22 October 2013; accepted: 29 October 2013; published online: 25 November 2013.

Citation: Häder D-P (2013) A grand challenge for environmental toxicity: what are the permissive limits of toxic pollutants in the environment? Front. Environ. Sci. 1:2. doi: $10.3389 /$ fenvs.2013.00002

This article was submitted to Environmental Toxicology, a section of the journal Frontiers in Environmental Science.

Copyright (c) 2013 Häder. This is an open-access article distributed under the terms of the Creative Commons Attribution License (CC BY). The use, distribution or reproduction in other forums is permitted, provided the original author $(s)$ or licensor are credited and that the original publication in this journal is cited, in accordance with accepted academic practice. No use, distribution or reproduction is permitted which does not comply with these terms. 